\title{
PENGARUH PENAMBAHAN SERAT IJUK TERHADAP KEKUATAN MORTAR BETON PAVING BLOCK
}

\author{
Oleh: Erlina ${ }^{1}$ \\ E-mail:erlinahakuan@gmail.com
}

\begin{abstract}
ABSTRAK: Pembuatan perkerasan jalan pada lingkungan perumahan dengan Paving Block salah satu cara konservasi air tanah dan pemanfaataan serat ijuk yangmerupakan upaya memberdayakan potensi lokal untuk. Penelitian ini bertujuan untuk mengetahui kuat tekan, kuat lentur, dan daya serap air pada Paving Block sebagai lapisan perkerasan dengan penggunaan Serat ljuk sebagai bahan tambah. Dengan benda uji berupa Paving Block dan bahan tambah berupa Serat ljuk. Penelitian dilakukan di Laboratorium Bahan UCY, melalui beberapa proses pencampuran, pengadukan, penuangan, dan pemadatan, serta curing (Perawatan), lalu dilakukan pengujian mortar segar maupun mortar keras.
\end{abstract}

Hasil penelitian yang dilakukan secara visual Pada Paving Block dengan penambahan serat ijuk terhadap semen berpengaruh pada kuat tekan yang berakibat mengalami kenaikan dan penurunan kuat tekan rata-rata untuk umur 7 hari $P B_{1}=0,99 \%, P B_{1,5}=0,87 \%, P B_{2}=0,87 \%$ terhadap paving block normal sebesar 0,98\%. Untuk umur 28 hari $P B_{1}=1,41 \%, P B_{1,5}=1,25 \%, P B_{2}=1,25 \%$ terhadap paving block normal sebesar $1,40 \%$. Sedangkan pada kuat lentur yang berakibat mengalami penurunan rata-rata terhadap kuat lentur untuk umur 7 hari $P B_{1}=0,54 \%, P B_{1,5}=$ $0,55 \%, P B_{2}=0,50 \%$ terhadap paving block normal sebesar 0,60\%. untuk umur 28 hari $P B_{1}=$ $0,77 \%, P B_{1,5}=0,79 \% P B_{2}=0,72 \%$ terhadap paving block normal sebesar $0,86 \%$. Sedangkan untuk penambahan serat ijuk terhadap paving block, mengalami penurunan pada daya serap air $P B_{1}=9,521 \%, P B_{1,5}=11,806 \%, P B_{2}=11,886 \%$ terhadap paving block normal sebesar 7,629 \% Dari hasil penelitian secara umum dengan penambahan serat ijuk terhadap semen paving block tidak memenuhi syarat kekuatan baik kuat tekan, kuat lentur maupun untuk daya serap airnya. Dengan demikian dari hasil penelitian ini belum memberikan nilai yang bermanfaat secara ekonomis pada masyarakat luas.

Kata kunci: Bahan tambah, daya serap air, kuat lentur, kuat tekan, serat ijuk

\section{PENDAHULUAN}

Pada dasarnya beton/motral adalah campuran antara bahan agregat (halus dan kasar) dengan pasta semen dan dengan perbandingan tertentu. Beton merupakan salah satu struktur yang banyak digunakan oleh masyarakat dalam pembangunan sarana fisik. Hal ini karenakan beton mempunyai beberapa kelebihan dibanding dengan bahan yang lain antara lain adalah beton mempunyai kuat tekan yang tinggi, bentuknya dapat dicetak sesuai dengan desain atau bentuk yang diinginkan, (Kardiyono,1992) menyatakan kelebihan Beton antara lain harganya relatif lebih murah dari pada baja, tidak memerlukan biaya perawatan seperti baja (baja harus selalu dicat dalam jangka waktu tertentu untuk mencegah karat) dan tahan lama karena tidak busuk atau berkarat. Disamping itu beton juga mempunyai kelemahan antara lain lebih getas mempunyai kembang susut akibat perubahan suhu dan kuat tarik rendah untuk mengatasi biasanya diberi tulangan. Serat ijuk merupakan salah satu bahan yang dihasilkan oleh pohon aren (aren pinora) dengan berupa serat-serat berwarna hitam berdiameter kurang dari $0,5 \mathrm{~mm}$, bersifat liat (tidak mudah putus). ljuk dapat dihasilkan pohon aren setelah berumur kurang lebih 5 tahun, pada pohon yang masih muda serat ijuk masih kecil dan kualitasnya rendah. Produksi ijuk dengan kualitas dan kuantitas baik berasal dari pohon aren yang tidak terlalu tua dan tidak terlalu muda (4-5 tahun), sebelum pohon aren berbunga dapat menghasilkan 30-50 lempeng ijuk. Beberapa keungulan yang dimiliki oleh serat ijuk diantaranya adalah bersifat lentur, tidak mudah rapuh dan sangat tahan

1) adalah staf pengajar Program Studi Teknik Sipil Universitas Cokroaminoto Yogyakarta 
terhadap genangan air asam dan air laut. Disisi lain serat ijuk memiliki kelemahan yaitu tidak tahan terhadap api sehinga mudah terbakar. Pesatnya pembangunan yang dilakukan masyarakat, baik perumahan maupun perkerasan jalan seiring menimbulkan masalah tentang ekologi tata air tanah yang harus mendapatkan perhatian kita bersama. Untuk itu perlu kita pikirkan bersama suatu cara atau system pembuatan jalan dan sasaran lingkungan yang dapat berfungsi sebagai bidang resapan. Pembuatan perkerasan jalan dan sasaran pada lingkungan perumahan dengan Paving Block salah satu cara yang dapat diterapkan, karena dengan adanya celah-celah antara Paving Block yang diisi pasir merupakan media yang dapat menyerap air yang selanjutnya dialirkan kelapisan dibawahnya.

Berbagai penelitian dan pengkajian bidang beton berupaya untuk meningkatkan kualitas dan mengurangi kelemahan. Dari hasil penelitian dan pengkajian dimaksud untuk memenuhi akan kebutuhan pemakaian beton serta kendala-kendala yang sering terjadi dalam pelaksanaan di lapangan, misalnya penyediaan bahan baku serta biaya yang harus dikeluarkan untuk mendapatkan bahan tambahan beton.

Penelitian yang dilakukan ini merupakan penelitian lanjutan dari beberapa penelitian tentang conblock sebelumnya. Adapun penelitian yang pernah dibahas adalah Tugas Akhir Sutriman, 2001, dengan judul Pengaruh Penggunaan Pasir Pantai Parangtritis Yogyakarta Terhadap Kuat Tekan dan daya serap Air Conblock. Endru Malvin 2005, dengan judul Pengaruh Penambahan Kawat Strimin Pada Kuat Tekan, Kuat Lentur dan Daya Serap air Pada Paving Block. Laporan hasil penelitian Nurokhman,1999, dengan judul Komparasi Kuat Tekan Mortal Dengan Pasir Asal Sungai Gelis, Sungai Krasak dan Sungai Progo, sehingga nantinya akan diperoleh hasil penelitian yang bervariasi. Menurut pengetahuan, penelitian tentang pengaruh penambahan Serat ljuk terhadap kuat tekan, lentur dan daya serap air pada paving block belum pernah dibahas, kalaupun ada terdapat perbedaan-perbedaan yang mendasar, misalnya faktor air semen, asal agregat, waktu penelitian dan perlakuan-perlakuan dalam penelitian yang berbeda pula.

\section{TINJAUAN PUSTAKA}

\subsection{Pengertian Umum}

Beton didapat dari campuran bahan-bahan agregat halus dan kasar yaitu pasir, batu pecah atau bahan semacam lainnya dengan menambahkan secukupnya bahan perekat. Semen dan air sebagai bahan yang membantu guna keperluan reaksi kimia selama proses pengerasan dan perawatan beton berlangsung. Kekuatan serta daya tahan beton merupakan fungsi dari banyak faktor, diantaranya adalah nilai banding campuran, mutu bahan susun, metode pelaksanaan, pengecoran, temperatur dan kondisi pekerjaannya (Dipohusodo 1996).

Mortar (sering disebut dengan mortal/spesi) adalah adukan yang terdiri dari pasir, bahan perekat dan air. Bahan perekat dapat berupa tanah liat, kapur, semen Portland, bila tanah liat yang dipakai sebagai perekat disebut mortar lumpur, bila yang dipakai kapur disebut mortar kapur, dan begitu pula bila yang dipakai semen Portland sebagai perekat disebut mortar semen, dan pasir sebagai bahan pengisi (bahan yang direkatkan), (Tjokrodimuljo, 1996)

Penggunaan mortar dalam pekerjaan kontruksi antara lain sebagai berikut (singh and singh, 1979) : (1) Digunakan pada pekerjaan bangunan untuk merekatkan batu bata atau balok beton, (2) Untuk memperoleh permukaan batu bara atau blok beton yang rata dan mencegah ketidakrataan sambungan, (3) Digunakan untuk memplester permukaan 
bangunan dan melindungi dari pengaruh cuaca dan memberi hasil akhir yang halus dan baik, (4) Pada beton, mortar digunakan unutk mengikat agregat kasar. Dan mMortar yang digunakan untuk pekerjaan bangunan (Tjokrodimuljo,1996) harus mudah dikerjakan, tahan lama, murah, melekat dengan baik pada beton dan sebagainya, cepat kering atau mengeras, tahan terhadap rembesan, dan tidak timbul retak-retak setelah dipasang.

Mortar dapat diklasifikasikan menjadi 3 jenis (1) Mortar Lumpur, (2) mortar kapur, mortar semen. Umumnya perbandingan volume semen dan pasir berkisar $1: 2$ sampai 1 : 6 atau lebih. Mortar ini lebih kuat dibanding dengan mortar lain, oleh karena itu mortar semen sering digunakan untuk tembok, pilar kolom, atau bagian lain yang menahan beban. Karena mortar ini rapat air maka juga digunakan untuk bagian luar dan yang ada dalam tanah. Pencampuran mortar tidak dengan penggilingan seperti pada mortar kapur. Semen dan pasir dicampur dalam keadaan kering pada tempat yang rata dan rapat air. Kemudian sebagian air yang diperlukan dapat tercampur seluruhnya. Untuk pekerjaan besar dengan suplai mortar diperlukan secara terus-menerus dapat digunakan dengan mesin pengaduk.

Selain mortar di atas, terdapat mortar khusus yang dibuat dengan menambahkan bahan khusus pada kapur dan mortar semen pada tujuan tertentu. Mortar ringan diperoleh dengan menambahkan asbestes fiber, jute fiber ( serat jerami ), butir-butir kayu, serbuk gergaji kayu, dan sebagainya. Mortar ini digunakan untuk bahan isolasi panas dan isolasi suara. Mortar tahan api diperoleh dengan menambahkan bubuk bata api dengan aluminous cement, dengan perbandingan volume 1 Aluminous Cement dan 2 bubuk bata api, mortar ini biasa dipakai untuk tungku api dan sebagainya.

\subsection{Kekuatan Mortar}

Bila dilihat dari bahan susunnya, Paving Block sama dengan mortar semen sehingga kekuatannya sama yaitu dipengaruhi oleh beberapa faktor. Secara umum faktor yang mempengaruhi kekuatan mortar dan beton antara lain (Tjokrodimuljo,1996): faktor air semen, umur beton, jenis semen, jumlah semen, sifat agregat, metode pencampurannya, cara pengolahan/pengadukan, dan cara perawatan.

\subsection{Paving block dengan serat ijuk}

Paving block dapat didefinisikan sebagai salah satu komposisi bahan yang dibuat dari campuran portland atau bahan perekat hidrolis sejenisnya, agregrat air dengan atau tanpa bahan tambahan lainnya yang tidak mengurangi mutu beton atau mortar tersebut. Pada suatu saat Paving block merupakan alternatif baru sebagai perkerasan yang sudah ada. Perkerasan dibagi menjadi 2 yaitu perkerasan kaku dan perkerasan lentur. Perkerasan lentur terbuat dari agregat dengan bahan ikat berupa aspal, sedangkan perkerasan kaku terbuat dari agregat dengan bahan ikat semen. Perbedaan kedua perkerasan terletak pada cara meneruskan beban lalu lintas ketanah dasar. Pada perkerasan kaku beban lalu lintas ketanah dasar dengan penyebarannya sangat luas sehingga beban yang diterima tanah dasar

kecil. Pada perkerasan lentur terdiri dari beberapa lapis, maka kemampuan meneruskan beban lalu lintas ketanah dasar tergantung pada kekuatan relatif dan tebal masing-masing lapisan serta kekuatan tanah dasarnya (Sudarmoko,2000).

Paving block muncul dengan sifat yang unik, dimana jika Paving block hanya satu buah maka akan bersifat seperti perkerasan kaku, tetapi jika Paving block dipasang bersama-sama akan mempunyai sifat seperti perkerasan lentur, perkerasan Paving block ditentukan oleh dua hal yaitu kuat tekan dari masing-masing Paving Block yang dibuat dari beton dengan mutu yang telah ditentukan dan gesekan antara elemen Paving Block dengan adanya pasir pengisi sela paving block. Kelebihan kontruksi paving block (a) biaya pemeliharaan ringan dan mudah untuk perbaikan sehingga gangguan operasional 
dapat ditekan serendah mungkin, (b) dapat dengan mudah dibongkar kembali tanpa menghilangkan kemampuan Paving block dalam menahan beban sehingga perbaikan perkerasan yang mengalami penurunan cukup besar menjadi cukup murah, (c) sangat tahan terhadap beban vertikal dan gaya horisontal yang disebabkan oleh pengiriman, perlambatan, atau percepatan kendaraan, serta pada kemampuan menahan beban peti kemas, (d) ketahanan tinggi terhadap bahan bakar minyak atau oli yang tumpah, (e) perkerasan Interlock dapat segera dibuka/dipakai lalu lintas setelah pemasangan selesai, (f) Paving block juga dapat diangkat jika terjadi penggalian untuk kabel lisrik, PDAM, telepon untuk kemudian dipasang kembali dengan biaya murah tanpa menimbulkan bekas.

Syarat mutu bata beton yang ditetapkan SII dalam Sudarmoko, (2000) adalah (a) sifat tampak bahan bata beton yang untuk lantai harus mempunyai bentuk yang sempurna, tidak terdapat retak-retak dan cacar bagian sudut dan rusaknya tidak bisa direpihkan dengan kekuatan jari tangan, (b) bentuk dan ukuran bata beton untuk lantai dapat tergantung dari persetujuan antara pemakai dan produsen. Setiap produsen harus memberikan penjelasan secara tertulis mengenai bentuk, ukuran dan kontruksi pemasangan bata beton untuk lantai, penyimpangan tebal beton untuk lantai diperkirakan $3 \mathrm{~mm}$, (c) sifat fisik bata beton pada Tabel 1.

Tabel 1. Kekuatan fisik bata beton untuk lantai (SII 0819-88)

\begin{tabular}{|c|c|c|c|c|c|}
\hline \multirow{2}{*}{ MUTU } & \multicolumn{2}{|c|}{ Kuat Tekan $\left(\mathrm{kg} / \mathrm{cm}^{2}\right)$} & \multicolumn{2}{c|}{ Ketahanan aus $(\mathrm{mm} / \mathrm{menit})$} & Penyerapan \\
\cline { 2 - 5 } & Rata-rata & Terendah & Rata-rata & Terendah & Air(\%) \\
\hline I & 400 & 340 & 0,090 & 0,103 & 3 \\
\hline II & 300 & 255 & 0,130 & 0,149 & 5 \\
\hline III & 200 & 170 & 0,160 & 0,184 & 7 \\
\hline
\end{tabular}

Perkembangan dunia teknologi beton telah menghasilkan beberapa solusi alternatif beton sereat, seperti serat ijuk. Serat alami yang berasal dari serat tumbuhtumbuhan seperti serat bambu, serat ijuk dapat dipakai dengan pertimbangan khusus pada penggunaan konvesional karena sifatnya yang tidak tahan lama. Hasil-hasil penelitian yang telah banyak dilakukan menunjukkan bahwa penambahan bahan serat pada adukan beton dapat meningkatkan sifat-sifat betonnya (Soehendro. 1991) 
a. Daktilitas (ductility), yang berhubungan dengan kemampuan untuk menyerap energi (energi absorbtion).

b. Ketahanan terhadap beban kejut (impact resistance)

c. Kemampuan menahan tarik dan momen lentur

d. Ketahanan terhadap kelelahan (fatique life)

e. Ketahanan terhadap pengaruh susutan (shrinkage)

f. Ketahanan terhadap susun (abrasion), fragmentasi (fragmentation) dan spalling. Penelitian Riyana (1996) dengan penambahan serat alami berupa serat ijuk dengan potongan sepanjang $\pm 4 \mathrm{~cm}$ pada beton non pasir, dalam lima variasi konsentrasi serat dari $0 \%$ sampai $2 \%$ memberikan petunjuk terjadinya penggumpalan serat (balling) selama proses pengadukan seiring dengan peningkatan konsentrasi serat.

Dari segi kekuatan, beton mempunyai kuat tekan dan kuat gaser yang cukup besar, tetapi di lain pihak memiliki kelemahan yang menonjol yaitu kuat tarik sangat rendah dan segera retak walaupun mendapat gaya tarik yang kecil saja, sehingga kuat tarik beton jarang diperhitungkan dalam perancangan suatu struktur. Para peneliti berusaha memperbaiki sifat-sifat kelemahan dari beton tersebut dengan cara menambahkan serat (fiber) pada adukan beton. Ide dasarnya adalah menulangi beton dengan serat yang disebarkan merata kedalam adukan beton dengan orientasi yang random, sehingga dapat mencegah terjadinya retakan-retakan beton yang terlalu dini akibat pembebanan (Soroushian dan Bayasi, 1987, dalam Soehendro,1991).

Menurut Tjokrodimuljo (1996) beton serat adalah bagian komposit yang terjadi dari beton biasa dan bahan lain yang berupa serat. Serta dapat dianggap sebagai agregat yang bentuknya sangat tidak bulat. Adanya serat mengakibatkan berkurangnya sifat kemudahan dikerjakan dan mempersulit terjadinya segregasi. Serat pada beton berperan dalam menambah kuat tarik beton sehingga beton serat lebih daktail daripada beton biasa dalam penyerapan energi.

Menurut Soehendro (1991), beberapa hal yang perlu mendapat perhatian khusus pada beton serat dalam campuran adukan beton adalah penyebaran serat (fiber dispersion) yakni teknik pencampuran adukan agar serat yang ditambahkan dapat tersebar merata dengan orientasi yang random dalam beton dan masalah kelecakan adukan (workability). Secara umum dapat dijelaskan bahwa dengan memodifikasi proporsi adukan (misalnya dengan menambahkan superplatilizer ataupun memperkecil diameter maksimum agregat), dan memodifikasi teknik pencampuran adukan (mixing technique) maka masalah fiber dispresion dapat diatasi. Untuk masalah workability, penelitian terdahulu menunjukkann bahwa penambahan serat akan menurunkan kemudahan pengerjaan adukan seiring dengan pertambahan serat dan aspek rasio serat (nilai banding panjang dan diameter serat). Aspek rasio serat yang tinggi akan menyebabkan serat pada adukan beton cenderung menggumpal (balling) sehinngga adukan sulit dikerjakan. Menurut penelitian Briggs dkk,1974 (Sudarmoko,1993) batas maksimum aspek rasio serat yang masih memungkinkan pengadukan dilakukan dengan mudah adalah 1/d kurang dari 100. Penelitian yang dilakukan oleh Soehendro (1991) membuktikan bahwa sifat-sifat kurang dari beton yaitu getas, praktis tidak mampu menahan tegangan tarik dan momen lentur dan ketahanan yang rendah terhadap impact dapat secara dramatis diperbaiki dengan menambahkan serat lokal pada adukan beton seperti serat alami, serat kawat baja, serat kawat biasa. Hasil penelitian Sudarmoko, 1993 (Tjokrodimuljo,1996) yang menambahkan serat alami berupa serat ijuk dengan potongan $\pm 4 \mathrm{~cm}$ pada adukan beton normal menunjukan penambahan serat $1 \%$ volume beton mampu meningkatkan kuat tekan beton sekitar $25 \%$, Kuat tarik sekitar $47 \%$

\section{METODE PENELITIAN}




\subsection{Bahan Susun}

Bahan susun yang digunakan dalam penelitian ini adalah semen portland merek Nusantara, pasir yang digunakan berasal dari kali Progo Yogyakarta dengan butiran lolos saringan 4,8 mm, air dari lingkungan di Laboratorium Bahan UCY, serat ljuk sebagai bahan tambahan yang terbuat dari pohon aren, kemudian di potong sepanjang $2 \mathrm{~cm}$ dengan porsentase campurannya bervariasi yaitu $1 \%, 1,5 \%$ dan $2 \%$.

\subsection{Alat yang diperlukan}

Alat yang digunakan di Laboratorium Bahan Bangunan, Jurusan Teknik Sipil Fakultas Teknik Universitas Cokroaminoto mulai dari persiapan pembuatan sampai tahap pengujian, adalah ayakan, timbangan, oven listrik, gelas Ukur, piknometer, cethok, cetakan paving block berupa bata yang terbuat dari polywood dengan ukuran $20 \times 10 \times$ $7 \mathrm{~cm}$, digunakan untuk mencetak benda uji kuat tekan dan daya serap air. Selain itu ada pula cetakan yang berukuran $30 \times 10 \times 7 \mathrm{~cm}$, yang digunakan untuk mencetak benda uji kuat lentur, kapiler, ember, mesin uji kuat tekan digunakan untuk pengujian kuat tekan paving block. Alat ini terdiri dari mesin tekan dan alat pengukur beban atau gaya yang mempunyai kapasitas 150 Ton, mesin uji kuat lentur digunakan untuk pengujian kuat lentur paving block. Alat ini terdiri dari mesin lentur dan alat pengukur beban atau gaya yang mempunyai kapasitas $15 \mathrm{KN}$.

\section{HASIL PENELITIAN DAN PEMBAHASAN}

Dari penelitian yang dilakukan dilaboratorium, dibawah ini akan disajikan hasil berupa data dan grafik kuat tekan dan kuat lentur umur 7 hari, 28 hari dan daya serap air. Dengan data-data hasil penelitian tersebut dilakukan analisis dan pembahasannya. Analisis penelitian berdasarkan prinsip statistik dan probabilitas dengan dasar SII 081988, dilakukan analisis dan pembahasan ekonomis komersial untuk mengetahui kelayakan pemasaran untuk tahap produksi masal yang titik beratnya pada bentuk fisik. Pembahasan ekonomis dititik beratkan terhadap biaya bahan baku dalam rangka menekan biaya produksi terutama biaya bahan baku.

\subsection{Analisis Daya Serap Air}

Dari hasil pengujian daya serap air pada paving block normal sebesar $7.629 \%$. Hasil ini lebih kecil dari syarat kekuatan paving block yang terendah (tingkat III) yaitu 7\%. Hal ini dikarenakan daya serap air di dalam Paving block dengan campuran serat ijuk yang memiliki daya serap air yang kurang bagus, selain itu faktor air semen (f.a.s) yang dapat mempengaruhi daya serap air pada Paving block. Berikut ini dapat di lihat daya serap air pada grafik 5.1 dibawah ini:

\subsection{Pengujian Kuat Tekan Paving Block}

Pengujian kuat tekan paving block bertujuan untuk mengetahui kekuatan maksimum Paving block apabila mendapat gaya tekan atau gaya desak. Pengujian kuat tekan Paving block dilakukan sebanyak satu kali, yaitu saat paving block berumur 7 dan pada umur 28 hari hasilnya di konversikan. Sampel benda uji pada umur 7 hari terdiri dari lima buah benda uji setiap variasi atau bahan susun. Dengan penambahan serat ijuk terhadap semen berpengaruh pada kuat tekan yang berakibat mengalami kenaikan dan penurunan kuat tekan rata-rata sebagai berikut: untuk umur 7 hari pada paving block dengan campuran serat ijuk $1 \%$ menghasilkan sebesar $0,99 \%$, pada paving block dengan campuran serat ijuk 1,5\% menghasilkan sebesar $0,87 \%$, pada paving block dengan campuran serat ijuk $2 \%$ menghasilkan sebesar $0,87 \%$ terhadap paving block normal sebesar 0,98\%. Untuk umur 28 hari hasilnya dikorelasi, pada paving block dengan campuran serat ijuk 1\% menghasilkan sebesar 1,41\%, pada paving block dengan 
campuran serat ijuk 1,5\% menghasilkan sebesar $1,25 \%$, pada paving block dengan campuran serat ijuk $2 \%$ menghasilkan sebesar $1,25 \%$ terhadap paving block normal sebesar 1,40\%. Dari hasil pengujian kuat tekan dari Tabel 5.2. dapat dibuat grafik hubungan kuat tekan paving block dengan umur paving block, yaitu dapat dilihat pada Gambar 1.

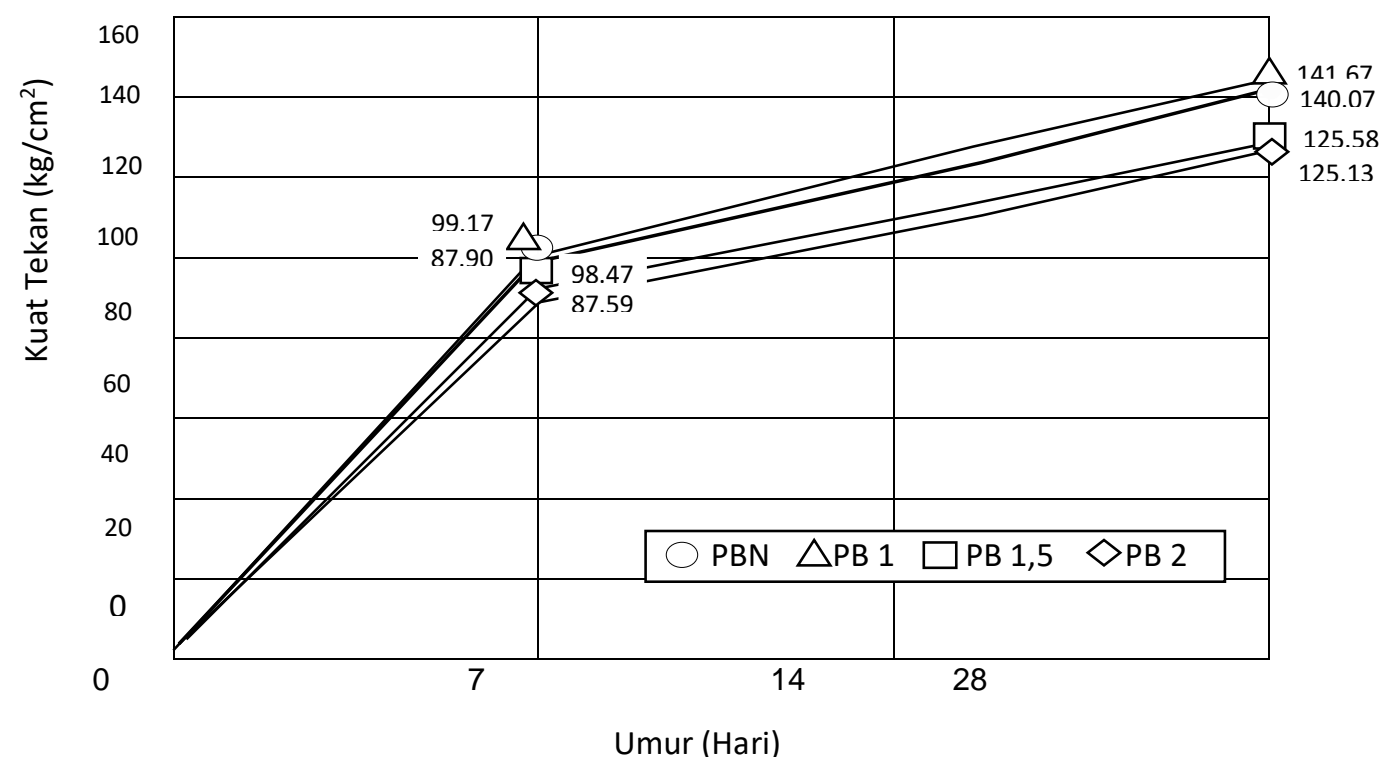

\section{Gambar 1. Grafik hubungan antara kuat tekan dan umur (hari)}

Berdasarkan pada grafik perbandingan kuat tekan paving block dapat disimpulkan bahwa kekuatan paving block dari masing-masing variasi proses penambahan serat ijuk mengalami kenaikan ketika umur Paving block bertambah ini disebabkan selama proses perendaman berlangsung udara yang ada pada paving block tidak terperangkap oleh pori-pori paving block sehingga ikatan antara bahan susun makin baik dan kuat serta tidak terpengaruh oleh suhu udara berlangsung sudah terjadi ikatan antara bahan susun dengan baik dan tidak terjadi retak-retak pada paving block. Dari hasil pengujian kuat tekan bila diplotkan dengan persyaratan Paving Block menurut SII 0819-88 maka kuat tekan paving block dengan bahan susun penambahan serat ijuk bila untuk paving block tidak ada yang masuk dalam persyaratan tersebut. Dari hasil pengujian kuat tekan tabel 5.2, selanjutnya dibuat grafik hubungan kuat tekan paving block dengan persentase campuran, yaitu grafik tersebut dapat dilihat pada Gambar 2 berikut ini. 


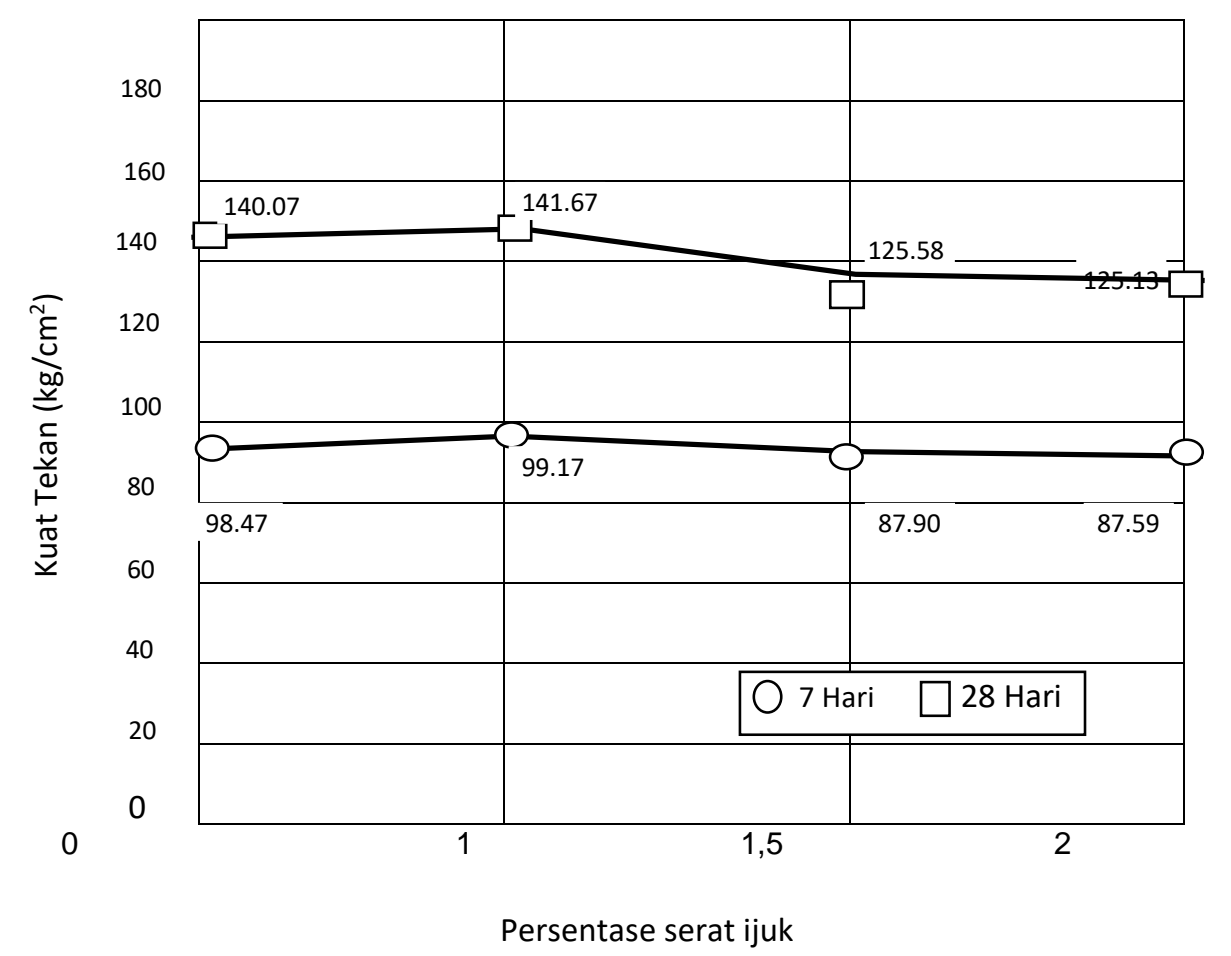

\section{Gambar 2. Hubungan nilai kuat tekan paving block dengan serat ijuk}

Berdasarkan gambar hubungan kuat tekan dan persentase penambahan serat ijuk diatas dapat disimpulkan, bahwa ketika serat ijuk bertambah, jumlah semen turun sehingga kekuatannya turun. Pengganti sebagian semen dengan serat ijuk ternyata tidak sebaik dengan semennya, walaupun serat ijuk merupakan salah satu bahan serat alami. Dari analisis penelitian yang dilakukan sebelumnya, berikut ini disajikan pembahasan kuat tekan. Dari tabel 1, sebelumnya dapat diketahui bahwa paving block penambahan serat ijuk belum memenuhi syarat yang ditentukan pada umur 28 hari dengan batas maksimal $170 \mathrm{~kg} / \mathrm{cm}^{2}$.

Dengan menggunakan tambahan serat ijuk sebagian penganti semen, makin menaikan kuat tekan paving block ini dapat dilihat pada gambar 1. Hal ini disebabkan karena bahan ikat yang ada didalam semen sedikit hilang, selain itu serat ijuk juga banyak menyerap air dan mampu menahan air didalam paving block masih basah didalamnya.

Begitu juga pula dengan penambahan serat ijuk sebagian penganti pasir dapat menurunkan kuat tekan paving block, ini dapat dilihat pada gambar 5.3. bahwa pada persentase campuran $1 \%$ mengalami peningkatan kuat tekan paving block dibanding paving block normal, namun pada persentase campuran lainnya mengalami penurunan. Semua variasi yang mengandung serat ijuk sebagian penganti pasir mengalami peningkatan yang cukup kecil karena serat ijuk sendiri cukup besar menyerap air serta dalam pencetakannya jumlah dan kekuatan pemukulan tidak sama karena peneliti dalam melakukan pembuatan benda uji dibantu teman. Dalam penelitian ini dilakukan pengujian pada umur 7 hari dan pada umur 28 hari hasilnya di konversikan. Angka yang ada pada umur 7 hari besarnya tidak sama dengan angka pada umur 28 hari. Sebab pada umur 28 hari hasilnya di konversikan, dibag dengan 0,70 kemudian diambil hasil rata-rata pada umur 28 hari. 
Pada variasi $1 \%$ kuat tekan mengalami kenaikan, namun pada variasi lainnya kuat tekan pada paving block mengalami penurunan

\subsection{Pengujian Kuat Lentur Paving block}

Pengujian kuat lentur paving block bertujuan untuk mengetahui kekuatan maksimum paving block apabila mendapat gaya lentur. Pengujian kuat lentur paving block dilakukan sebanyak satu kali, yaitu saat paving block berumur 7 hari dan pada saat umur 28 hari hasilnya di konversikan. Masing-masing umur benda uji terdiri dari lima buah benda uji setiap variasi atau bahan susun.

Dengan penambahan serat ijuk terhadap semen berpengaruh pada kuat lentur yang berakibat mengalami penurunan terhadap kuat lentur sebagai berikut: untuk umur 7 hari pada paving block dengan campuran serat ijuk 1\% menghasilkan sebesar 0,54\%, pada paving block dengan campuran serat ijuk 1,5\% menghasilkan sebesar 0,55\%, pada paving block dengan campuran serat ijuk $2 \%$ menghasilkan sebesar $0,50 \%$ terhadap paving block normal sebesar $0,60 \%$ untuk umur 28 hari hasilnya dikorelasi, pada paving block dengan campuran serat ijuk $1 \%$ menghasilkan sebesar $0,77 \%$, pada paving block dengan campuran serat ijuk 1,5\% menghasilkan sebesar $0,79 \%$, pada paving block dengan campuran serat ijuk $2 \%$ menghasilkan sebesar $0,72 \%$ terhadap paving block normal sebesar $0,86 \%$. Dari hasil pengujian kuat lentur, dapat dibuat grafik hubungan kuat lentur paving block dengan umur paving block, yaitu dapat dilihat pada Gambar 3.

Berdasarkan grafik diatas dapat diambil pengertian bahwa dengan bertambahnya umur paving block, berpengaruh pada kuat lentur yaitu diikuti dengan kenaikan kuat lenturnya. Dari hasil pengujian kuat lentur, dapat dibuat grafik hubungan kuat lentur paving block dengan persentase penambahan serat ijuk, yaitu grafik dapat dilihat pada Gambar 4 berikut ini.

Berdasarkan gambar hubungan kuat lentur dan persentase campuran serat ijuk diatas dapat disimpulkan, bahwa ketika serat ijuk bertambah, jumlah semen turun sehingga kekuatannya lenturnya semakin menurun. Pengganti sebagian semen dengan serat ijuk ternyata sebaik dengan semennya, walaupun serat ijuk merupakan salah satu bahan serat alami. Dari analisis penelitian yang dilakukan sebelumnya, berikut ini disajikan pembahasan kuat lentur. Dari tabel 4, sebelumnya dapat diketahui bahwa paving block penambahan serat ijuk belum memenuhi syarat yang ditentukan pada umur 28 hari dengan batas maksimal $100 \mathrm{~kg} / \mathrm{cm}^{2}$.

Dengan menggunakan tambahan serat ijuk sebagian penganti semen, makin menurun kuat lentur paving block ini dapat dilihat pada gambar 5.5. Hal ini disebabkan karena bahan ikat yang ada didalam semen sedikit hilang, selain itu serat ijuk juga banyak menyerap air dan mampu menahan air didalam paving block masih basah didalamnya. Begitu juga pula dengan penambahan serat ijuk sebagian penganti pasir dapat menurunkan kuat lentur paving block, ini dapat dilihat pada gambar 5.5. bahwa semua variasi mengalami penurunan kuat lentur paving block dibanding paving block normal. Semua variasi yang mengandung serat ijuk sebagian penganti pasir mengalami penurunan yang cukup kecil karena serat ijuk sendiri cukup besar menyerap air serta dalam pencetakannya jumlah dan kekuatan pemukulan tidak sama karena peneliti dalam melakukan pembuatan benda uji dibantu teman. 


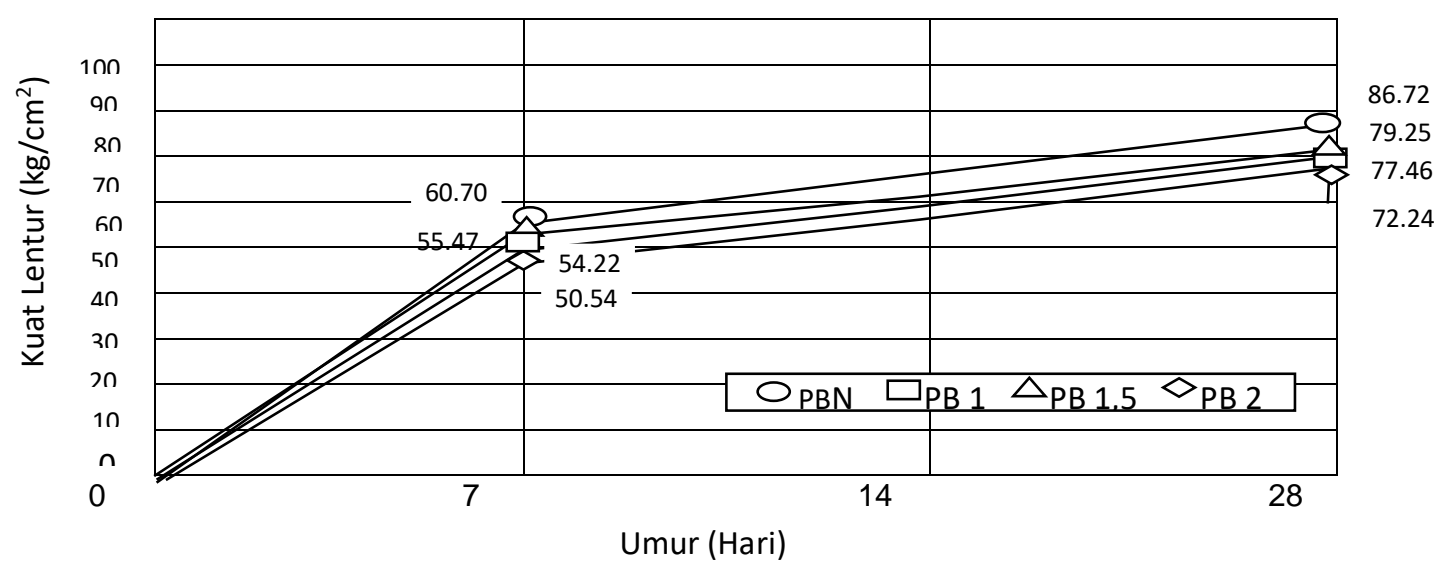

Gambar 3. Grafik hubungan antar kuat lentur dan umur (hari)

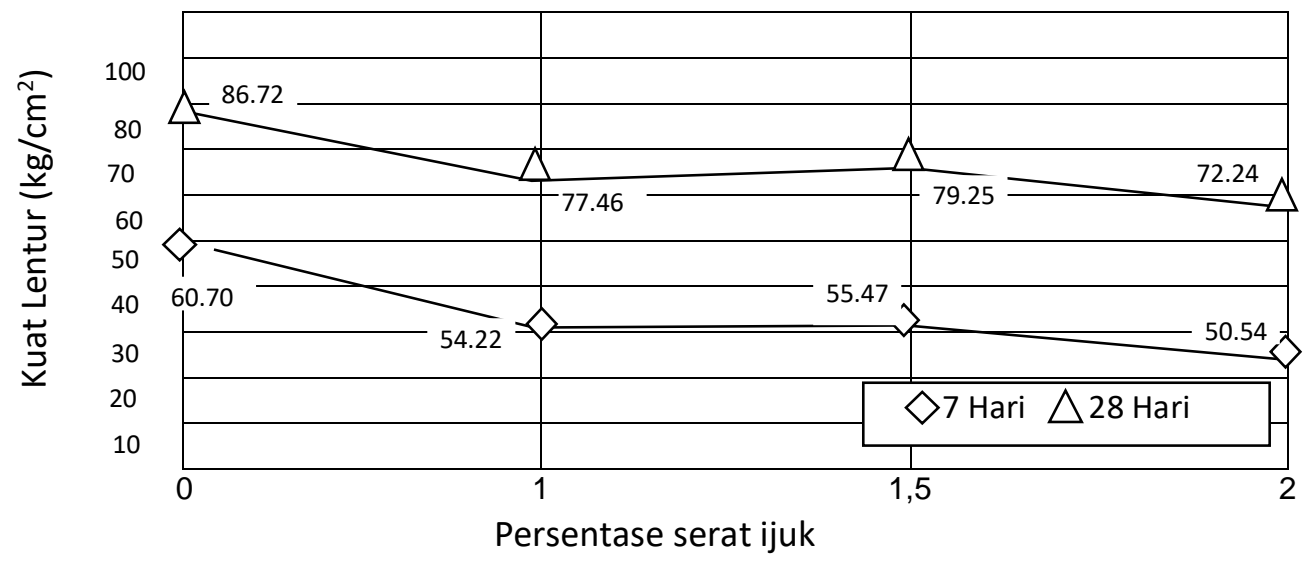

Gambar 4. Hubungan kuat lentur Paving Block dengan Serat ljuk

Dalam penelitin ini dilakukan pengujian ada umur 7 dan pada umur 28 hari hasilnya dikonversikan. Angka yang ada pada umur 7 hari besarnya tidak sama dengan angka pada umur 28 hari. Sebab perbedaan ini terletak pada pembagian hasil umur 7 hari dibagi dengan 0,70 . Pada variasi lain mengalami kenaikan dan penurunan kuat lentur sehingga angka yang didapat berbeda. Hal ini terjadi pada semua jenis variasi paving block.

10 Pengaruh Penambahan Serat Kayu ljuk Terhadap Kekuatan Mortar Beton Paving Block (Erlina) 


\section{KESIMPULAN DAN SARAN}

Dari pengujian di laboraturium, pengamatan dilapangan serta pembahasan pada bab sebelumnya, maka dapat ditarik kesimpulan dari hasil penelitian sebagai berikut:

a. Dengan penambahan serat ijuk terhadap semen berpengaruh pada kuat tekan yang berakibat mengalami kenaikan dan penurunan kuat tekan rata-rata sebagai berikut: untuk umur 7 hari $\mathrm{PB}_{1}=0,99 \%, \mathrm{~PB}_{1,5}=0,87 \%, \mathrm{~PB}_{2}=0,87 \%$ terhadap paving block normal sebesar 0,98\%. Untuk umur 28 hari $\mathrm{PB}_{1}=1,41 \%, \mathrm{~PB}_{1,5}=1,25 \%, \mathrm{~PB}_{2}=1,25 \%$ terhadap paving block normal sebesar $1,40 \%$.

b. Dengan penambahan serat ijuk terhadap semen berpengaruh pada kuat lentur yang berakibat mengalami penurunan terhadap kuat lentur sebagai berikut: untuk umur 7 hari $\mathrm{PB}_{1}=0,54 \%, \mathrm{~PB}_{1,5}=0,55 \%, \mathrm{~PB}_{2}=0,50 \%$ terhadap paving block normal sebesar $0,60 \%$. untuk umur 28 hari $\mathrm{PB}_{1}=0,77 \%, \mathrm{~PB}_{1,5}=0,79 \%, \mathrm{~PB}_{2}=0,72 \%$ terhadap paving block normal sebesar 0,86\%.

c. Dengan penambahan serat ijuk terhadap paving block berpengaruh pada daya serap air, mengalami penurunan $\mathrm{PB}_{1}=9,521 \%, \mathrm{~PB}_{1,5}=11,806 \%, \mathrm{~PB}_{2}=11,886 \%$ terhadap paving block normal sebesar 7,629 \%.

d. Dari hasil analisis ekonomi komersial pada Paving Block dengan campuran serat ijuk, belum cukup layak untuk dipasarkan dan di peroduksi secara masal.

e. Dari hasil penelitian secara umum dengan penambahan serat ijuk terhadap paving block tidak memenuhi syarat kekuatan, baik kuat tekan dan kuat lenturbegitu juga untuk daya serap airnya belum memenuhi syarat. Dengan demikian dari hasil penelitian ini belum memberikan nilai yang bermanfaat secara nilai ekonomisnya pada masyarakat luas.

\section{DAFTAR PUSTAKA}

Anonim, 1993. Pedoman Pelaksanaan Pratikum Beton, Laboratorium Struktur dan Bahan, Jurusan Teknik Sipil, Fakultas Teknik, Universitas Gajah Mada, Yogyakarta.

Anonim, 2000. Pedoman Pelaksaaan Pratikum, Laboratorium Bahan Teknik, Jurusan Teknik Sipil dan Perencanaan Universitas Islam Indonesia, Yogyakarta.

Dipohusodho, I, 1999. Struktur Beton Bertulang Berdasarkan SK SNI T-15-1999-03 Departemen Pekerjaan Umum, PT G

Haning, 1993. Pedoman Penggunaan Paving Block Pada Perkerasan, Yayasan Departemen Pekerjaan Umum

Kardiyono Tjokrodimulyo, 1992. Bahan Bangunan, Jurusan Teknik Sipil, Fakultas Teknik, Universitas Gajah Mada, Yogyakarta.

Kardiyono Tjokrodimulyo, 1995. Teknologi Beton, Jurusan Teknik Sipil, Fakultas Teknik, Universitas Gajah Mada, Yogyakarta.

Pusat Penelitian dan Pengembangan Pemukiman, 1992. PERSYARATAN Umum Bahan Bangunan Indonesia (PUBI-1982), Badan Penelitian Dan Pengembangan P.U. Bandung. 